\title{
Preliminary investigations on picoplankton-related precipitation of alkaline-earth metal carbonates in meso-oligotrophic lake Geneva (Switzerland)
}

\author{
Jean-Michel JAQUET, ${ }^{*}$ Pascale NIREL, ${ }^{2}$ Agathe MARTIGNIER ${ }^{1}$ \\ ${ }^{1}$ Section des Sciences de la Terre et de l'Environnement, Université de Genève, 13 rue des Maraîchers, CH-1205 Geneva; ${ }^{2}$ Service \\ d'Ecologie de l'Eau, Département de l'Intérieur, Mobilité et Environnement (DIME), 23 rue Ste. Clotilde, CH-1211 Geneva, Switzerland \\ *Corresponding author: jean-michel.jaquet@unige.ch
}

\begin{abstract}
In the course of a routine water-quality survey in meso-oligotrophic lake Geneva (Switzerland), suspended matter was collected by filtration on $0.2 \mu \mathrm{m}$ membranes in July and August 2012 at the depth of maximal chlorophyll a (Chl a) concentration (2 mg $\left.\mathrm{m}^{-3}\right)$. Examination by scanning electron microscopy revealed the presence of numerous dark and gelatinous patches occluding the pores of the membranes, containing high numbers of picoplanktonic cells and, in places, clusters of medium-to-high-reflectance smooth microspheres (0.6 $\mathrm{\mu m}$ in diameter). Their chemical composition, determined by semi-quantitative, energy-dispersive X ray spectrometry (EDS) showed magnesium (Mg), calcium (Ca), strontium ( $\mathrm{Sr}$ ) and barium (Ba) (alkaline earth metals) to be the dominant cations. Among the anions, phosphorus $(P)$ and carbon $(C)$ were present, but only the latter is considered here (as carbonate). The microspheres were subdivided into four types represented in a Ca-Sr-Ba ternary space. All types are confined within a domain bound by $\mathrm{Ca}>45, \mathrm{Sr}<10$ and Ba<50 (in mole \%). Type I, the most frequent, displays a broad variability in Ba/Ca, even within a given cluster. Types II and III are devoid of $B a$, but may incorporate P. Type IV contains only Ca. The Type I composition resembles that of benstonite, a Group IIA carbonate that was recently found as intracellular granules in a cyanobacterium from alkaline lake Alchichica (Mexico). Lake Geneva microspheres are solid, featureless and embedded in a mucilage-looking substance in the vicinity of, but seemingly not inside, picoplanktonic cells morphologically similar to Chlorella and Synechococcus. In summer 2012, the macroscopic physico-chemical conditions in lake Geneva epilimnion were such as to allow precipitation of Ca but not of Sr and Ba carbonates. Favourable conditions did exist, though, in the micro-environment provided by the combination of active picoplankton and a mucilaginous envelope. Further studies are ongoing to investigate the vertical distribution of the microspheres, their internal structure and their exact mineralogical composition, as well as the taxonomy of the picoplankton and the nature of the mucilage, in order to gain a proper understanding of this intriguing process of alkaline-earth metals sequestration.
\end{abstract}

Key words: Bio-mediated carbonate precipitation, alkaline-earth metals, freshwater, picoplankton.

Received: March 2013. Accepted: June 2013.

\section{INTRODUCTION}

Calcium carbonate $\left(\mathrm{CaCO}_{3}\right)$ precipitation in lacustrine environment is now a well-documented phenomenon. It occurs in hard- to moderately hard-water lakes such as, for example, Constance (Stabel, 1986), Zurich (Kelts and Hsu, 1978) and Bourget (Groleau et al., 2000). An earlier work on lake Geneva showed calcite to be oversaturated in the epilimnion between April and August (Jaquet et al., 1983).

Autochtonous calcite precipitation is dependent on water temperature and $\mathrm{pH}$, the latter increasing with phytoplanktonic primary production. Particulate matter, whether living (plankton and bacteria) or inert (organic or mineral detritus), plays an important role in heterogeneous calcite nucleation, a process at work in natural waters in which saturation index $(S I)$ is too low to trigger homogeneous nucleation (Stabel, 1986).

Picoplankton, as prokaryotic cyanobacteria (e.g. Synechococcus), or small eukaryotic phototrophs (e.g. Chlorella), is now recognised as a significant part of autotrophic plankton in lakes as diverse as Baikal (Belykh and Sorokovikova, 2003), Huron (Fahnenstiel et al., 1991), Tahoe (Winder, 2009) and Maggiore (Callieri and Piscia, 2002). In this last case, it is said to successfully compete with nanoplankton in periods of phosphorus (P) limitation. Picoplankton can be an important actor in $\mathrm{CaCO}_{3}$ precipitation process, as confirmed by laboratory experiments and field study in lake Lucerne (Dittrich et al., 2004; Dittrich and Obst, 2004). Various strains of $S y$ nechococcus have been tested for their potential to sequestrate atmospheric $\mathrm{CO}_{2}$ (Lee et al., 2006; Jansson and Northen, 2010). This genus has also been found to be active in calcite ooid formation in western lake Geneva (Plée et al., 2008), closely associated to biofilms.

The presence of extracellular polymeric substances (EPS) in biofilms is a key factor in the model of Dupraz et al. (2009), which states that organomineralisation can be divided into two coupled elements: i) an alkalinity engine, driven internally by microbial metabolism or externally by the environment (temperature); and ii) an organic 
matrix in which mineralisation will take place. Cyanobacteria (Pereira et al., 2009; Dittrich and Sibler, 2010) and some strains of Chlorella (Watanabe et al., 2006) are known to secrete extracellular polysaccharides, which may act as binding sites for $\mathrm{Ca}^{2+}$ and $\mathrm{CO}_{3}{ }^{2-}$. The importance of biofilms in freshwater carbonate precipitation has been demonstrated by Rogerson et al. (2008) in their experiments on tufa systems.

In contrast to $\mathrm{CaCO}_{3}$, data on precipitation of other alkaline-earth metals (AEM) such as strontium ( $\mathrm{Sr}$ ) and barium $(\mathrm{Ba})$ are scarcer. This is understandable, as the concentration of these elements in lake water is much lower (molar ratio $\mathrm{Ba}: \mathrm{Sr}: \mathrm{Mg}: \mathrm{Ca}$ is of the order of 1:40:1900:8200 in lake Geneva), with saturation indices for $\mathrm{Sr}$ and $\mathrm{Ba}$ carbonates well below zero under normal physico-chemical conditions.

In the marine environment, biogenic Ba preferably precipitates as sulfate (barite) within dead phytoplankton aggregates (abiotic precipitation) (Jeandel et al., 2000), or under the direct influence of biological processes (Gonzalez-Muñoz et al., 2012).

In lake Constance, $\mathrm{Sr}$ has been found to co-precipitate with calcium $(\mathrm{Ca})$ in calcite, while a $\mathrm{Ca}$-independent $\mathrm{Sr}$ uptake by biota is negligible (Stabel et al., 1986; Stabel, 1989). According to Stabel et al. (1991), the water of this lake is always undersaturated with respect to $\mathrm{SrCO}_{3}$ (strontianite), not to mention $\mathrm{BaCO}_{3}$ (witherite).

Barium and Sr sulfates (barite and celestite) are known to be present as biominerals in the terminal vacuoles of freshwater Desmids such as Closterium and Micrasterias (Brook, 1980; Wilcock et al., 1989; Krejci et al., 2011). Barium carbonate (as witherite) has been reported to be precipitated as fibrous crystals by bacteria (Sanchez-Moral et al., 2004). Another avenue for precipitation of AEM is given by the prostomatid ciliates Loxodes and Remanella, whose müllerian vesicles contain, respectively, Ba and $\mathrm{Sr}$ salts (Finlay et al., 1983; McGrath et al., 1989; Lynn, 2010).

It is only recently that a well-identified amorphous carbonate containing magnesium $(\mathrm{Mg}), \mathrm{Ca}, \mathrm{Sr}$ and $\mathrm{Ba}$ (attributed to a benstonite-like phase) was found in highly alkaline lake Alchichica microbialites by Couradeau et al. (2012). In this case, the carbonate is precipitated as intracellular inclusions in a novel cyanobacterium (candidatus Gloeomargarita lithophora).

Within the framework of ongoing water-quality surveys undertaken by the Service de l'écologie de l'eau (SECOE) in Petit-Lac (the southwestern part of lake Geneva), suspended matter was collected in 2012 by filtration at the depth of maximum chlorophyll $a(\mathrm{Chl} a)$ concentration. Examination by scanning electron microscopy (SEM) coupled to energy-dispersive X-ray spectrometry (EDS) revealed, in July and August samples, the presence of Mg-Ca-Sr-Bacontaining microspheres, seemingly related to mucilage packaging picoplanktonic cells.
We present here preliminary investigations conducted by SEM/EDS on the microsphere samples currently available. This study is part of a series of geomicrobiological analyses conducted in lake Geneva (Jaquet et al., 1982; Plée et al., 2008; Glas-Haller, 2010).

\section{METHODS}

Petit-Lac represents the southwest portion of Léman or lake Geneva. After undergoing eutrophication in the 1980s and 1990s (Anneville and Pelletier, 2000), this hard-water lake is now in the process of re-oligotrophication. Data on physico-chemistry, phytoplankton, zooplankton and fish production is available in the French-Swiss Commission yearly reports (CIPEL, 2011; Lazarotto and Klein, 2012). Recent studies on phytoplankton can be found in Anneville et al. (2002) and Gallina et al. (2011).

Monthly measurements of physico-chemistry and water samples were taken at GE3 station $\left(6.22^{\circ} \mathrm{E} / 46.30^{\circ} \mathrm{N}\right)$ at 10 different depths ranging 0 to $70 \mathrm{~m}$ with a plastic Niskin ${ }^{\circledR}$ bottle. Also, continuous recording of $\mathrm{Chl} a$ and turbidity was done by means of a Wet Labs ${ }^{\circledR}$ probe (Wet Labs, Philomath, OR, USA). Phytoplankton was collected by means of an integrating sampler over the top $20 \mathrm{~m}$, and taxa were identified and counted following Utermöhl method. A larger water volume (10-15 L) was sampled at the depth of maximum Chl $a$ concentration, followed by gentle vacuum filtration in the lab within a few hours on return from the field. For gravimetry, Whatman ${ }^{\circledR}$ GF/F membranes (Whatman Ltd., Maidstone, UK) were used, and Schleicher \& Schuell ${ }^{\mathbb{B}}$ nitrocellulose (NC 60; $0.6 \mu \mathrm{m}$ ) (Schleicher \& Schuell BioScience GmbH, Dassel, Germany) as well as Millipore ${ }^{\circledR}$ polycarbonate (PC GTTP; $0.2 \mu \mathrm{m}$ ) (Millipore, Billerica, MA, USA) for SEM/EDS. Filters were air-dried, and no fixation was applied on this first set of samples. Sub-samples of filters were mounted on aluminum stubs covered with double-sided conductive carbon tape. A coating of gold ( $c a 15 \mathrm{~nm}$ ) or carbon $(\mathrm{ca} 15 \mathrm{~nm}$ ) was then deposited on the samples prior to imaging with a Jeol ${ }^{\circledR}$ JSM 7001F SEM (Jeol Ltd., Tokyo, Japan) (Department of Earth Sciences, Section of Earth and Environmental Sciences, University of Geneva, Switzerland) with an acceleration voltage of $15 \mathrm{kV}$. Semi-quantitative elemental analyses were performed with a JED2300 EDS detector (Jeol Ltd.; working distance: $10 \mathrm{~mm}$ ).

Carbonate species concentrations and calcite saturation index $\left[S I=\log \left(I A P / K_{S}\right)\right]$ were calculated using the software Aqion 2.5.1 (www.aqion.de), based on USGS PHREEQC (Parkhurst and Appelo, 1999) and the thermodynamical database wateq $4 f$ (Ball and Nordstrom, 1991).

This preliminary study concerns two suspended matter samples in which microspheres were present. They were collected in 2012: i) on $10^{\text {th }}$ July at $6 \mathrm{~m}$ depth [polycarbonate (PC) filter numbers 16 and 17, carbon coated] and ii) on $7^{\text {th }}$ August at $6 \mathrm{~m}$ depth [(PC filters 20, 21 (carbon coated) and 30 (gold coated)]. Clusters of microspheres 
were identified visually on the stubs at a magnification of 1000x and numbered as specimens ( $\operatorname{Spx} y-z$, where $x=1$ for 10.07.12, $x=2$ for 07.08.12; $y=$ cluster number and $z=$ microsphere number).

In order to verify the analytical results obtained by EDS on the microspheres, the mineral benstonite $\left[\mathrm{Mg} \mathrm{Ca}_{6}\right.$ $\left.\left(\mathrm{Ba}_{\mathrm{x}} \mathrm{Sr}_{\mathrm{y}}\right)\left(\mathrm{CO}_{3}\right)_{13}\right]$ (with $\mathrm{x}+\mathrm{y}=6$ ) was synthesised following a modification of Hood and colleagues' procedure (Hood and Steidl, 1973; Hood et al., 1974). The precipitate was aged for three days prior to SEM/EDS analysis. It consists of spherical aggregates of nanoparticles (Supplementary Fig. 1), similar in shape to $\mathrm{CaCO}_{3}$ or $\mathrm{SrCO}_{3}$ polymorphs reported by Wu et al. (2004), Sun et al. (2006) and Sondi and Matijevic (2003). The precipitate attribution to benstonite was confirmed by X-ray diffraction (XRD) (Supplementary Fig. 2) and Raman spectroscopy (Supplementary Fig. 3).

\section{RESULTS}

\section{Limnological context}

The microsphere-containing suspended matter samples were collected both times in fairly similar conditions
(Fig. 1a): at $6 \mathrm{~m}$ in the metalimnion, corresponding to the peak concentration of Chl $a\left(2 \mathrm{mg} \mathrm{m}^{-3}\right.$ on both dates $)$ and with a turbidity around 1 NTU.

The water was saturated, with respect to calcite, down to $7 \mathrm{~m}$ in July and $10 \mathrm{~m}$ in August (Tab. 1, Fig. 1b). Other interesting features are the molar ratios (in solution) $\mathrm{Sr} / \mathrm{Ca}$, around 0.0050 , similar to lake Constance values as mentioned by Stabel et al. (1986), and $\mathrm{Sr} / \mathrm{Ba}$, which is higher in the epilimnion (43-45.5; Fig. 1c), practically mimicking the $\mathrm{Chl} a$ profile (Fig. 1a). Analytical results (Tab. 1) indicate, at $5 \mathrm{~m}$ depth, higher temperature, $\mathrm{pH}, \mathrm{Sr} / \mathrm{Ba}$ and calcite saturation values (0.34 vs 0.13) in August. These $\mathrm{Sr} / \mathrm{Ba}$ maximums were not observed during our other campaigns in 2012 (data not shown).

Fig. 2 shows the phytoplankton groups found in July and August integrated over the top $20 \mathrm{~m}$ of the water column. Because of the integration, this may not represent exactly the taxa living at $6 \mathrm{~m}$ depth. Moreover, apart from Chlorella sp., it does not include picoplankton, which is omnipresent in the SEM images. In terms of biomass, diatoms (Bacillariophyceae) largely dominate in July, with a)

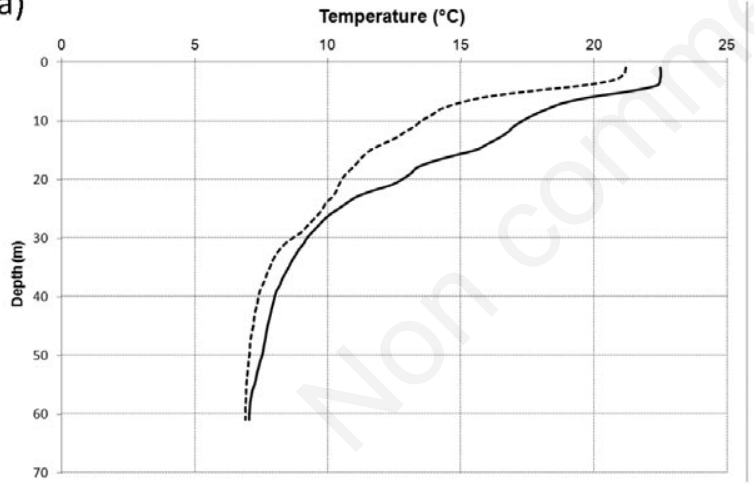

b)

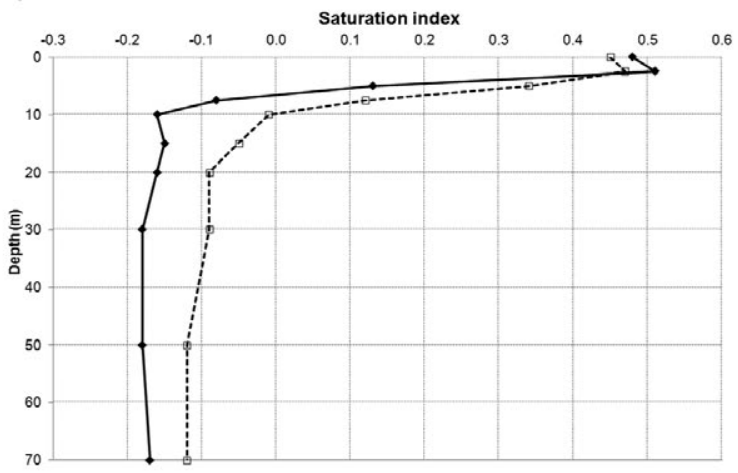

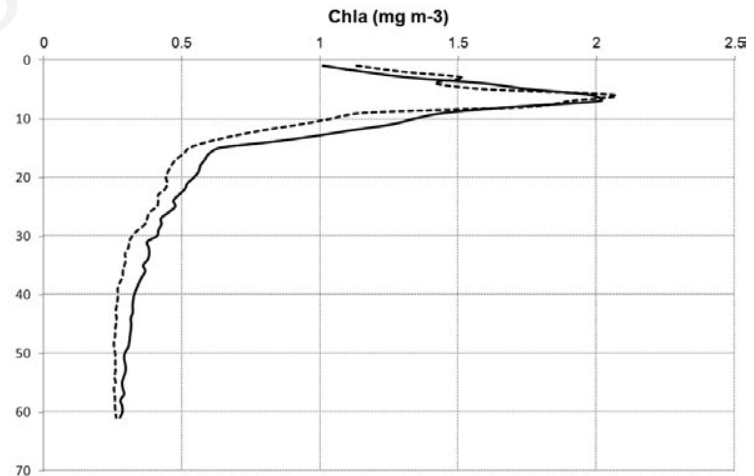

c)

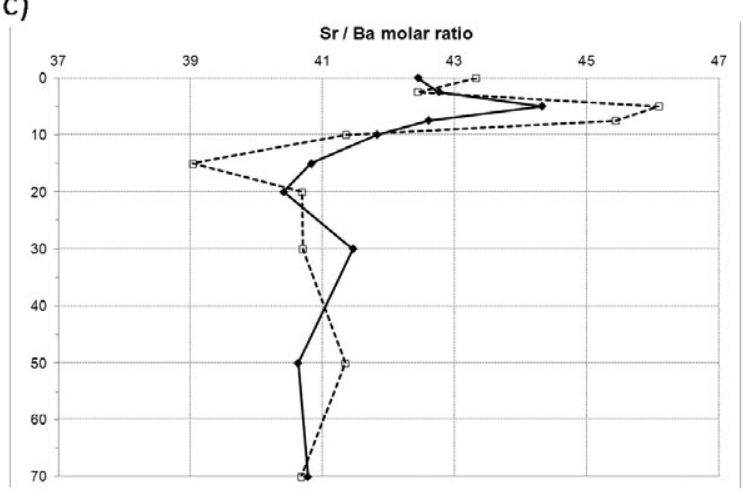

Fig. 1. a) Temperature and chlorophyll $a$ concentration profiles at GE3 station on $10^{\text {th }}$ July (dashed line) and $7^{\text {th }}$ August (solid line) 2012; b) corresponding calcite saturation index (samples with saturation index $>0$ are saturated with respect to calcite); c) $\mathrm{Sr} / \mathrm{Ba}$ molar ratio. 
lesser amounts of Chlorophyceae, Cryptophyceae and Dinophyceae. In August, the diatoms biomass decreases at the expense of the Chlorophyceae (mostly Chlorella sp., with abundance around $210^{3}$ cell $\mathrm{mL}^{-1}$ ). No measurements were carried out for water samples at the $\mathrm{Chl} a$ maximum. However, for lake Geneva in August (upper $15 \mathrm{~m}$ ), Personnic et al. (2009) report picocyanobacterial abundance values up to $310^{5}$ cell $\mathrm{mL}^{-1}$.

\section{Overall morphology of suspended matter}

The general aspect of the suspended matter collected on $10^{\text {th }}$ July (concentration: $2.6 \mathrm{mg} \mathrm{L}^{-1}$ ) and $7^{\text {th }}$ August (concentration: $1.8 \mathrm{mg} \mathrm{L}^{-1}$ ) is shown in Figs. 3 and 4, respectively. An obvious feature of both samples is the presence of dark patches, very likely of mucilaginous nature, which obliterate the membrane pores.

Low reflectance picoplanktonic cells, either spherical (Fig. 5a, right) or ellipsoidal (Fig. 6a), are densely packed within the mucilage patches. Their dimension is of the order of the $\mu \mathrm{m}$. In places, the patches contain clusters of high-reflectance, spherical or subspherical bodies (Fig. $5 \mathrm{a}$ ), with diameters varying between 0.6 and $3 \mu \mathrm{m}$. These microspheres are described in detail below. The mucilage embedding the clusters and picoplanktonic is electronically quasi-transparent, and its limits can be quite sharp and sub-circular (white arrows in Fig. 6a and 6b), suggesting an originally spherical shape prior to the deposition on the filter and subsequent collapse through drying. The presence of this organic matrix is further confirmed by a fortunate feature stemming from electron damage, visible on Fig. 6c: whereas most of the microspheres' contours are blurred by the organic coating (Hernández Mariné et al., 2004), the cracks reveal the presence of underlying, bare, sharply delimited microspheres (within white frames in Fig. 6c).

Calcium carbonate is present as isolated crystals $(>5$ $\mu \mathrm{m}$ ) or aggregates (Fig. 6a), showing signs of corrosion (Fig. 5a). These do not have any visible relationship with mucilage.

In July (Fig. 3), suspended matter contained, in addition to picoplankton, nano- and microplankton (Fig. 2): centric and pennate diatoms and chrysophyte siliceous scales. Ceratium hirundinella and diatoms (Achnanthes sp.) (Fig. 4) were present in August.

Tab. 1. Chemical composition of water at GE3 station (selected elements) and in lake Alchichica aquarium (from Couradeau et al., 2012).

\begin{tabular}{|c|c|c|c|c|c|c|c|c|}
\hline $\begin{array}{l}\text { Depth } \\
\text { (m) }\end{array}$ & $\begin{array}{c}\mathrm{T} \\
\left({ }^{\circ} \mathrm{C}\right)\end{array}$ & $\mathrm{pH}$ & $\begin{array}{l}\text { Alkalinity } \\
(\mu \mathrm{M} L-1)\end{array}$ & $\begin{array}{c}\mathrm{Mg} \\
(\mu \mathrm{M} \mathrm{L}-1)\end{array}$ & $\begin{array}{c}\mathrm{Ca} \\
(\mu \mathrm{M} \mathrm{L}-1)\end{array}$ & $\begin{array}{c}\mathrm{Sr} \\
(\mu \mathrm{M} \mathrm{L}-1)\end{array}$ & $\begin{array}{c}\mathrm{Ba} \\
(\mu \mathrm{M} \mathrm{L}-1)\end{array}$ & $\begin{array}{c}\text { SI } \\
\text { calcite }\end{array}$ \\
\hline \multicolumn{9}{|c|}{10.07 .2012} \\
\hline 0 & 20.6 & 8.52 & 1570 & 235 & 910 & 5.2 & 0.12 & 0.48 \\
\hline 2.5 & 20.0 & 8.55 & 1590 & 235 & 930 & 5.2 & 0.12 & 0.51 \\
\hline $5^{*}$ & $16.0^{*}$ & $8.14^{*}$ & $1730^{*}$ & $235^{*}$ & $1004^{*}$ & $5.3^{*}$ & $0.12^{*}$ & $0.13^{*}$ \\
\hline 7.5 & 13.3 & 7.92 & 1810 & 235 & 1059 & 5.4 & 0.13 & -0.08 \\
\hline 10 & 12.2 & 7.86 & 1820 & 235 & 1059 & 5.3 & 0.13 & -0.16 \\
\hline 15 & 10.6 & 7.84 & 1870 & 240 & 1094 & 5.5 & 0.13 & -0.15 \\
\hline 20 & 9.6 & 7.83 & 1880 & 240 & 1104 & 5.4 & 0.13 & -0.16 \\
\hline 30 & 7.4 & 7.84 & 1880 & 240 & 1109 & 5.5 & 0.13 & -0.18 \\
\hline 50 & 6.4 & 7.86 & 1890 & 240 & 1104 & 5.5 & 0.13 & -0.18 \\
\hline 70 & 6.4 & 7.86 & 1890 & 240 & 1124 & 5.5 & 0.14 & -0.17 \\
\hline $\begin{array}{l}\text { Alchichica } \\
\text { aquarium }\end{array}$ & 24 & 8.9 & 13617 & 6955 & 47 & 0.013 & 0.001 & 0.158 \\
\hline \multicolumn{9}{|c|}{05.08 .2012} \\
\hline$\overline{0}$ & 22.4 & 8.5 & 1480 & 232 & 868 & 5.0 & 0.12 & 0.45 \\
\hline 2.5 & 21.8 & 8.52 & 1480 & 233 & 882 & 5.0 & 0.12 & 0.47 \\
\hline $5^{*}$ & $19.4^{*}$ & $8.38^{*}$ & $1560^{*}$ & $232^{*}$ & $924^{*}$ & $5.0^{*}$ & $0.11^{*}$ & $0.34^{*}$ \\
\hline 7.5 & 17.4 & 8.11 & 1620 & 241 & 994 & 5.1 & 0.11 & 0.12 \\
\hline 10 & 16.4 & 8 & 1650 & 235 & 986 & 5.2 & 0.12 & -0.01 \\
\hline 15 & 13.6 & 7.91 & 1720 & 238 & 1052 & 5.1 & 0.13 & -0.05 \\
\hline 20 & 11.3 & 7.89 & 1790 & 236 & 1072 & 5.2 & 0.13 & -0.09 \\
\hline 30 & 8.2 & 7.88 & 1880 & 249 & 1145 & 5.5 & 0.13 & -0.09 \\
\hline 50 & 6.7 & 7.9 & 1880 & 244 & 1123 & 5.4 & 0.13 & -0.12 \\
\hline 70 & 6.3 & 7.9 & 1880 & 245 & 1131 & 5.5 & 0.13 & -0.12 \\
\hline
\end{tabular}

Mg, magnesium; Ca, calcium; Sr, strontium; Ba, barium; SI, saturation index of calcite (aragonite in Alchichica). *Approximate depth of occurrence of studied microspheres. 


\section{Alkaline-earth metals precipitates}

\section{Structure}

Fifty-five individual microspheres were characterised by SEM and analysed by EDS (Tab. 2). Their morphology can be inferred from SEM photographs in Figs. 5 and 6. They are spherical or sub-spherical and, prior to EDS analysis at least, display a very smooth and featureless surface. Their diameter varies between 0.6 and $3 \mu \mathrm{m}$. When struck by the electron beam, a small hole generally appears in the microsphere, which then exhibits damage consisting of cracks and surface alteration (darker punctuations; Figs. 5b and 5c). These features seem to be the expression of bubbles developing inside the microspheres. Notice that adjacent microspheres are also affected, being within the electron beam interaction volume of a few cubic $\mu \mathrm{m}$ (white circle in Fig. 5b). In some other instances (Fig. 5c), the electron action induces desquamation of the microspheres, which then appear to be composed of several successive layers a few nm thick. In all cases, these bodies seem to consist of a solid, seemingly amorphous substance (at least at the magnification of the SEM, and pending verification by electron diffraction).

\section{Chemical composition}

The microspheres investigated so far have been grouped in five types on the basis of their chemical composition, determined by EDS semi-quantitative analyses checked by reference to a synthetic benstonite standard. The type numbers and names with averages and minima/maxima are listed in Tab. 2, and the individual microspheres' positions in the $\mathrm{Ca}-\mathrm{Sr}$-Ba molar ternary space are shown in Fig. 7. So far, we found 35 microspheres belonging to type I, seven from type II and V, three from type III and only one from type IV. Because of the relatively small sample size (55 clusters), these numbers do not necessarily reflect the true proportion of the various types.

In Tab. 2, the major potential cations are $\mathrm{Ca}$ (always present), $\mathrm{Ba}$ and $\mathrm{Sr}$, with minor amounts of $\mathrm{Mg}$ and potassium $(\mathrm{K})$. Only in type $\mathrm{V}$ could $\mathrm{P}$ act as a potential anion. However, in this type, there is a severe charge imbalance (Tab. 2, last columns) if $\mathrm{P}$ is under the orthophosphate form. This anomaly is hitherto unexplained. In the other groups, we had to postulate the presence of $\mathrm{CO}_{3}{ }^{2-}$, because carbon cannot be validly analysed with the EDS configuration at our disposal. This can be justified by the carbonate hardness of lake Geneva water and by the findings by Couradeau et al. (2012), who report the presence of intracellular granules of an unusual benstonite-like phase, a carbonate (Tab. 3, last column) very similar to our microspheres. In the present paper, we shall deal only with types I, II, III and IV (alkaline-earth metal carbonates), setting aside type $\mathrm{V}$ to a further study.

Energy-dispersive X-ray spectrometry mapping was carried out to check the distribution of, chiefly, $\mathrm{Mg}, \mathrm{Ca}$, $\mathrm{Sr}$ and $\mathrm{Ba}$ among the various components of suspended matter. An example is given in Fig. 8a (cluster Sp2_4,

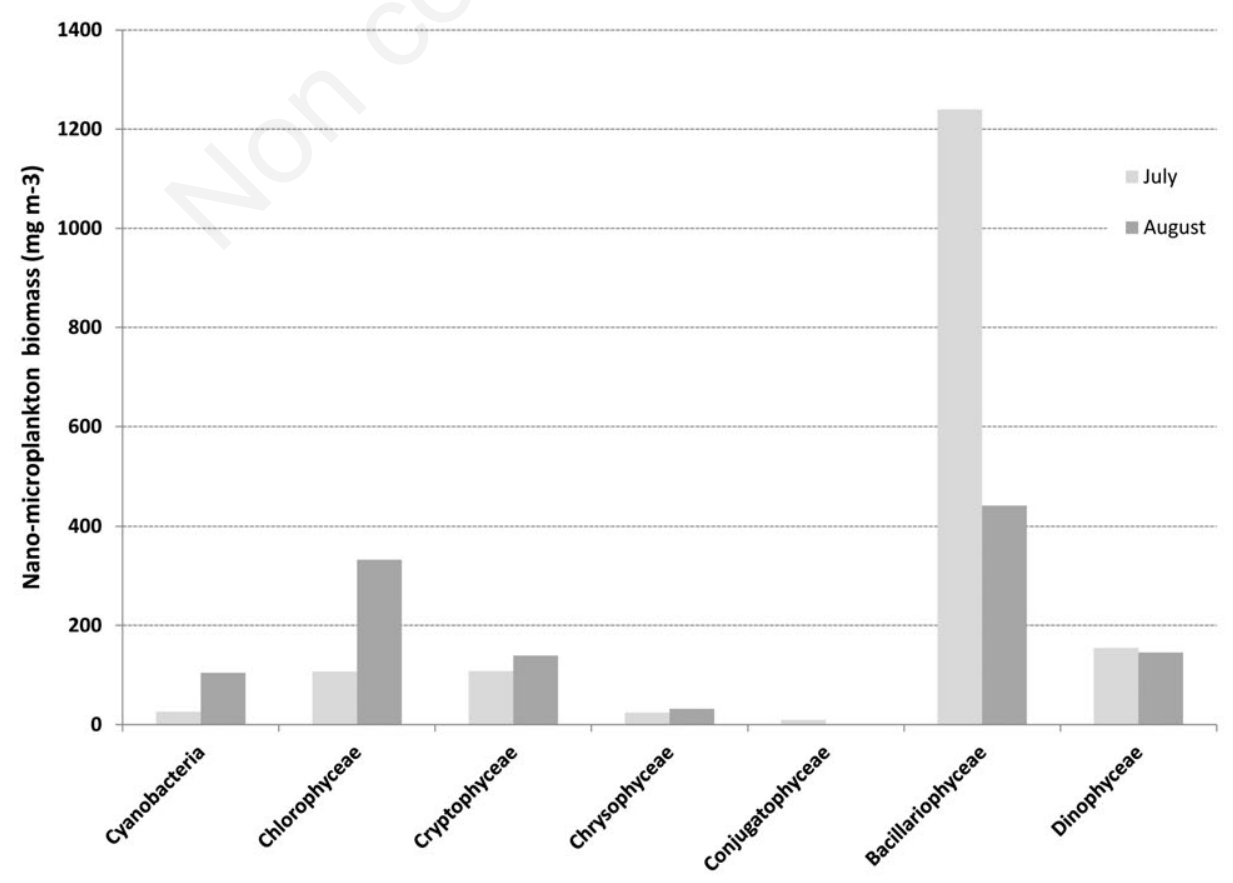

Fig. 2. Biomass of nano-microphytoplankton groups at GE3 station (0-20 m integration) in July and August 2012. 
Tab. 2. Microspheres average composition (atom \%).

\begin{tabular}{|c|c|c|c|c|c|c|c|c|c|c|c|c|c|c|c|c|c|c|}
\hline \multirow{2}{*}{$\begin{array}{l}\text { Type } \\
\text { Name } \\
\text { Element }\end{array}$} & \multicolumn{4}{|c|}{$\begin{array}{c}\mathrm{I} \\
\mathrm{CaSrBa}\end{array}$} & \multicolumn{4}{|c|}{$\begin{array}{c}\text { II } \\
\mathrm{CaSr}\end{array}$} & \multicolumn{4}{|c|}{$\begin{array}{c}\text { III } \\
\text { CaPSr }\end{array}$} & \multicolumn{2}{|c|}{$\begin{array}{l}\text { IV } \\
\mathrm{Ca}\end{array}$} & \multicolumn{4}{|c|}{$\begin{array}{c}\mathrm{V} \\
\mathrm{CaP}\end{array}$} \\
\hline & Mean & $\mathrm{N}$ & Min & Max & Mean & $\mathrm{N}$ & Min & Max & Mean & $\mathrm{N}$ & Min & Max & Mean & $\mathrm{N}$ & Mean & $\mathrm{N}$ & Min & Max \\
\hline $\mathrm{Mg}$ & 0.5 & 35 & 0.0 & 2.2 & 0.4 & 7 & 0.3 & 0.8 & 1.2 & 3 & 0.8 & 1.7 & 1.0 & 1 & 3.5 & 7 & 1.4 & 10.6 \\
\hline $\mathrm{P}$ & 1.2 & 3 & 0.0 & 2.0 & & & & & 5.0 & 3 & 3.4 & & & & 53.5 & 7 & 45.0 & 60.2 \\
\hline $\mathrm{S}$ & & & & & & & & & 2.5 & 1 & 2.5 & 2.5 & & & 12.4 & 2 & 1.3 & 23.4 \\
\hline K & & & & & & & & & & & & & & & 8.4 & 2 & 7.2 & 9.5 \\
\hline $\mathrm{Ca}$ & 32.0 & 35 & 19.5 & 64.1 & 90.1 & 7 & 87.0 & 92.4 & 82.7 & 3 & 76.3 & 87.5 & 99.0 & 1 & 37.1 & 7 & 23.0 & 43.1 \\
\hline $\mathrm{Sr}$ & 4.7 & 35 & 0.4 & 10.1 & 9.5 & 7 & 7.3 & 12.2 & 10.3 & 3 & 6.6 & 16.0 & & & & & & \\
\hline $\mathrm{Ba}$ & 62.8 & 35 & 30.7 & 75.5 & 0.0 & 7 & & & & & & & & & & & & \\
\hline \multicolumn{19}{|l|}{ As $100 \%{ }^{*}$} \\
\hline $\mathrm{Ca}$ & 32.2 & & 19.6 & 64.4 & 90.5 & & 87.3 & 92.8 & 88.9 & & 82.1 & 94.2 & 100.0 & & 100.0 & & & \\
\hline $\mathrm{Sr}$ & 4.7 & & 0.4 & 10.1 & 9.5 & & 7.3 & 12.3 & 11.1 & & 7.1 & 17.2 & 0.0 & & 0.0 & & & \\
\hline $\mathrm{Ba}$ & 63.1 & & 30.9 & 76.0 & 0.0 & & & & 0.0 & & & & 0.0 & & 0.0 & & & \\
\hline
\end{tabular}

$N$, number of analyses for a given element; Min, minimum; Max, maximum; $M g$, magnesium; $P$, phosphorus; $S$, sulphur; K, potassium; Ca, calcium; Sr strontium; Ba, barium. ${ }^{*}$ Three last rows: $\mathrm{Ca}$, Sr and Ba normalised to $100 \%$.

Tab. 3. Composition (atom \%, alkaline-earth elements) of benstonite varieties.

\begin{tabular}{|c|c|c|c|c|c|}
\hline Ratio & $\begin{array}{c}\left(\mathrm{Ba}_{5.5} \mathrm{Sr}_{0.5}\right) \\
\text { theoretical } \\
1\end{array}$ & $\begin{array}{l}\left(\mathrm{Ba}_{4.5} \mathrm{Sr}_{1.5}\right) \\
\text { theoretical* } \\
2\end{array}$ & $\begin{array}{c}\left(\mathrm{Ba}_{4.5} \mathrm{Sr}_{1.5}\right) \\
\text { synthetic } \\
\text { EDS }\end{array}$ & $\begin{array}{c}(\mathrm{BaSr})_{6} \\
\text { Anthony et al. } \\
(2012)\end{array}$ & $\begin{array}{c}\left(\mathrm{Ba}_{2.7} \mathrm{Sr}_{1.0} \mathrm{Mg}_{1.4} \mathrm{Ca}_{0.9}\right) \\
\text { Couradeau et al. } \\
(2012)\end{array}$ \\
\hline $\mathrm{Mg}$ & 2.3 & 2.4 & 1.3 & 2.3 & 18.0 \\
\hline $\mathrm{Ca}$ & 22.6 & 23.7 & 20.8 & 22.9 & 53.2 \\
\hline $\mathrm{Sr}$ & 4.1 & 13.0 & 11.2 & 4.1 & 8.1 \\
\hline $\mathrm{Ba}$ & 71.0 & 60.9 & 66.7 & 70.7 & 20.7 \\
\hline
\end{tabular}

EDS, energy dispersive X-ray spectrometry; $\mathrm{Mg}$, magnesium; Ca, calcium; $S r$, strontium; Ba, barium. ${ }^{*}$ Computed from formula; ${ }^{\circ}$ analysed semi-quantitatively by EDS on a polished surface. First row: variable cations, in addition to fixed $M g_{1} C_{6}$; last column: recomputed from Table S2 in Couradeau et al. (2012).

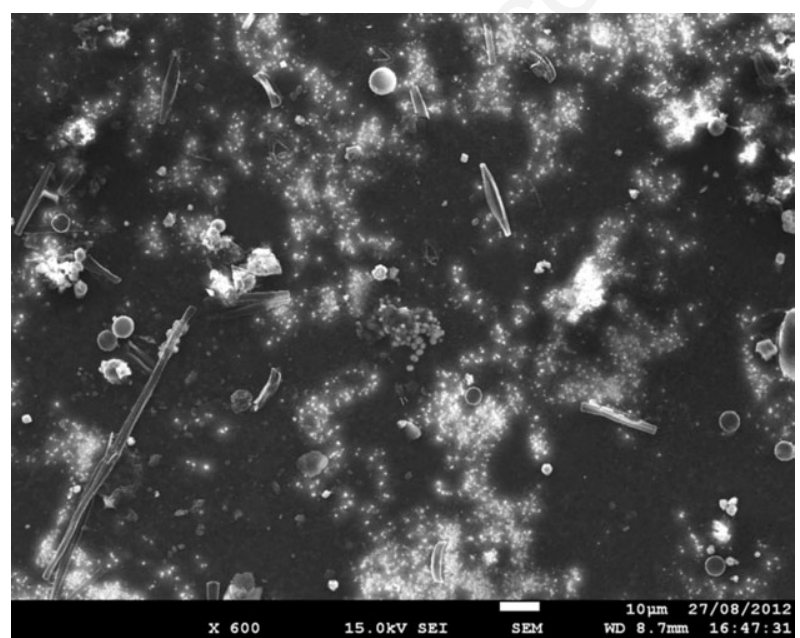

Fig. 3. General view of suspended matter from $10^{\text {th }}$ July 2012 (6 m depth), deposited on $0.2 \mu \mathrm{m}$ polycarbonate membrane, carbon coated. Scale bar: $10 \mu \mathrm{m}$. Centric and pennate diatoms, $\mathrm{CaCO}_{3}$ as white aggregates. Darker parts are interpreted as mucilage packaging picoplanktonic cells (see Figs. 5-7 for further details). Sp1_1 cluster of microspheres is visible at the centre of the figure.

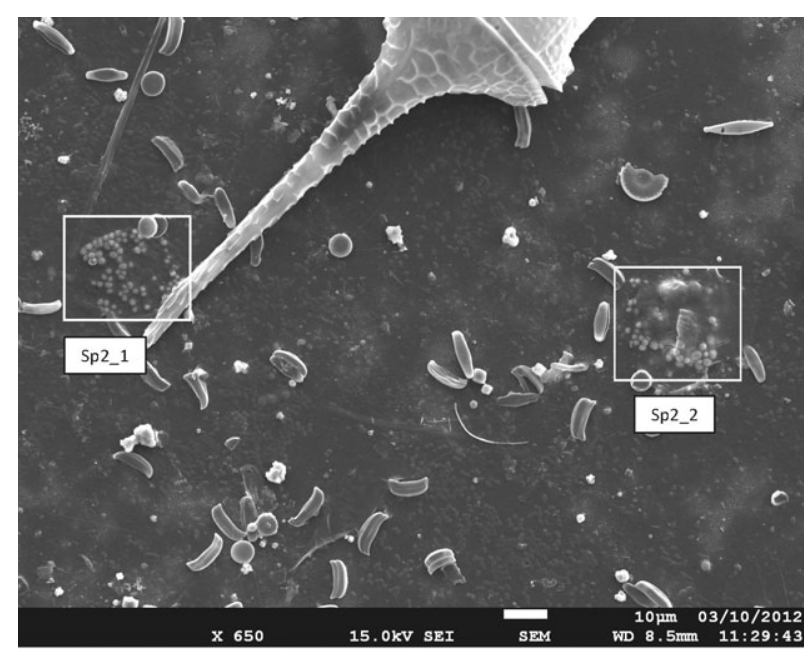

Fig. 4. General view of suspended matter from $7^{\text {th }}$ August 2012 (6 m depth), deposited on $0.2 \mu \mathrm{m}$ polycarbonate membrane, gold coated. Scale bar: $10 \mu \mathrm{m}$. Apical horn of Ceratium hirundinella. Numerous Achnanthes sp. diatoms, $\mathrm{CaCO}_{3}$ are also visible. Darker parts are believed to be mucilage packaging picoplanktonic cells (see Fig. 6a and $6 \mathrm{~b}$ for further details). Two clusters of microspheres are labelled $S p 2 \_1$ and $S p 2 \_2$ (in white frames). 
07.08.2012). In this specimen, $\mathrm{Ca}$ and $\mathrm{Ba}$ are exclusively concentrated in the microspheres, some of which may be rather small. The $\mathrm{Sr}$ and silicon ( $\mathrm{Si}$ ) maps are similar due to peak overlaps (Fig. 8b).

\section{DISCUSSION}

\section{Chemical composition in terms of dissolved alkaline-earth metals}

The concentrations of $\mathrm{Ca}, \mathrm{Sr}, \mathrm{Ba}$ and their seasonal variations are quite similar in lake Geneva and lake Constance (Stabel et al., 1991), where these elements are depleted in epilimnion during summer. In lake Geneva, the ratios $[\mathrm{Me}]_{5 \mathrm{~m}} /[\mathrm{Me}]_{70 \mathrm{~m}}$ computed from Tab. 1 were, in August 2012, Mg: 0.95, Ca: 0.82, Sr: 0.90 and $\mathrm{Ba}: 0.85$. Hence, it seems that $\mathrm{Ca}$ and $\mathrm{Ba}$ are slightly more depleted
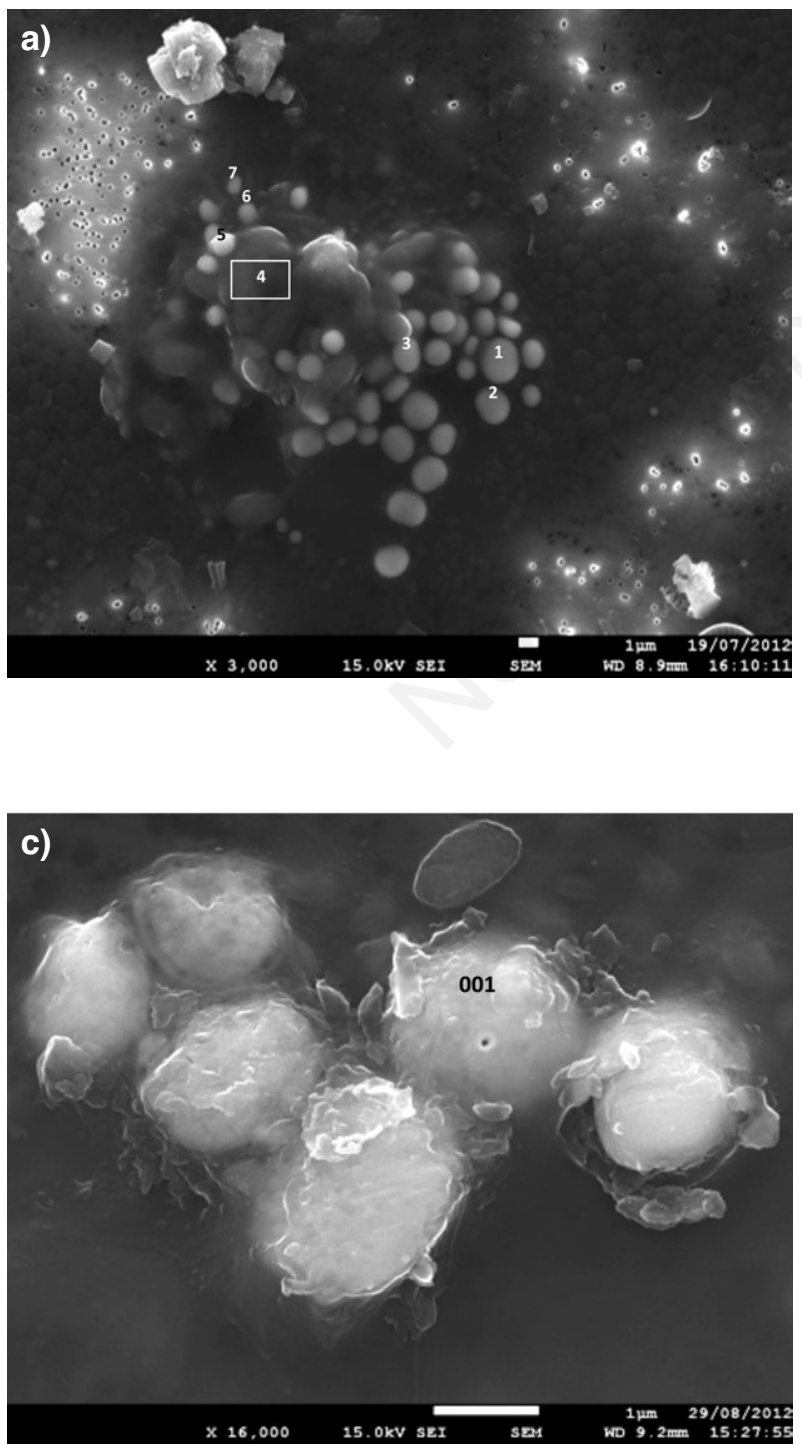

than $\mathrm{Mg}$ and $\mathrm{Sr}$, as an echo to the composition of the microspheres, $\mathrm{Ca}$ and $\mathrm{Ba}$ representing more than $90 \%$ of the cations (Tab. 2) in type I microspheres. In lake Constance, $\mathrm{Sr}$ and $\mathrm{Ba}$ are said to co-precipitate with calcite at an almost constant stoichiometry in particulate material (molar $\mathrm{Sr} / \mathrm{Ca}=0.0084$; atom $\mathrm{Sr} / \mathrm{Ca}=0.018$ ). This could also be the case in lake Geneva, with additional scavenging by the biologically mediated precipitation of specific amorphous AEM carbonates. In contrast, there is no sign of a decrease in Ba concentration towards the bottom (Tab. 1), as in lake Biwa, through adsorption on hydrous manganese oxides (Sugiyama et al., 1992).

\section{Physico-chemical framework for microspheres precipitation}

It is not known whether amorphous AEM carbonate

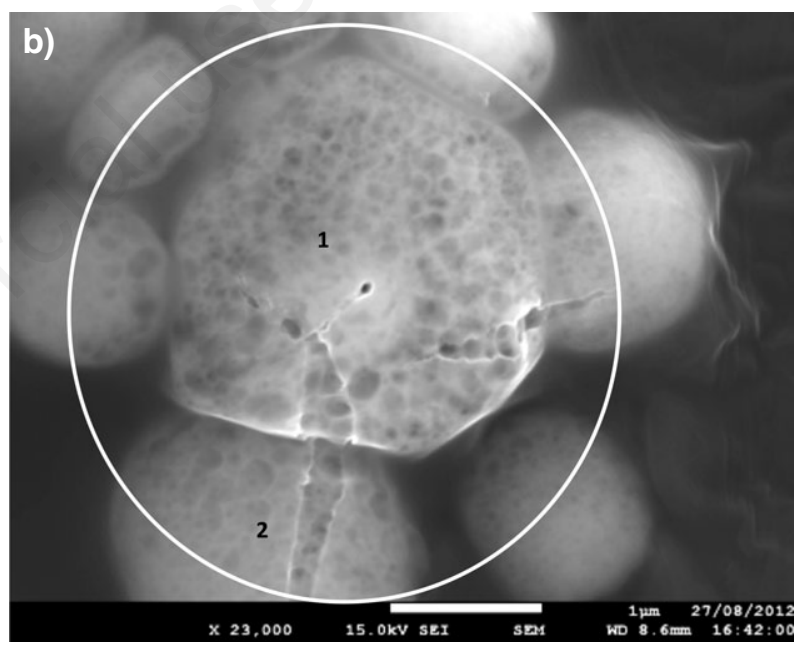

Fig. 5. a) Close-up view of microsphere cluster Sp1_1 (10.07.2012; from centre of Fig. 3). Scale bar $=1 \mu \mathrm{m}$, carbon coated. Parts of membrane uncovered by extracellular polymeric substances are lighter, with $0.2 \mu \mathrm{m}$ pores well visible. Extracellular polymeric substances-covered parts are darker, and show densely-packed, spherical cells $1 \mu \mathrm{m}$ or less in diameter, with associated microspheres. Numbers refer to individual microspheres that have been analysed by energy-dispersive X-ray spectrometry (EDS) (as points or rectangle). A large $\mathrm{CaCO}_{3}$ grain is visible on top. Scanning electron microscopy photograph taken prior to EDS analysis of microspheres (compare with Fig. 5b); b ) close-up view of microspheres 1 and 2 in cluster Spl_1 (10.07.2012). Scale bar: $1 \mu \mathrm{m}$. Scanning electron microscopy photograph taken after EDS analysis. Notice bubbly structure and cracks due to electron ray action within the volume of primary excitation of energy-dispersive $\mathrm{X}$ ray spectrometry (EDS) analysis (white circle); c) close-up view of microspheres in cluster Sp1_2 (10.07.2012). Scale bar: $1 \mu \mathrm{m}$. Microspheres seem to consist of several successive pellicles. Notice the hole due to EDS point analysis in Sp1_2001. Image taken after EDS analysis. 
(AAEMC) microspheres existed at other depths and dates than those found by chance in summer 2012. We only know they occurred in the thermocline, near the Chl $a$ concentration or biomass maximum, in waters saturated with respect to calcite and at a depth where the dissolved $\mathrm{Sr} / \mathrm{Ba}$ molar ratio was maximal (Fig. 1). It is, therefore, not unreasonable to postulate that there is a link between microsphere precipitation and phytoplanktonic primary production (PP) (primary production and phytoplankton biomass maxima generally coincide in lake Geneva) (Tadonleke, 2012). This is substantiated by the close spatial association of microspheres and picoplankton visible in SEM images (Figs. 5a and 6a).

If the macroscopic physico-chemical conditions (saturation index $>0$; Tab. 1) enable the precipitation of calcite crystals, the situation is different for the AAEMC. Al-
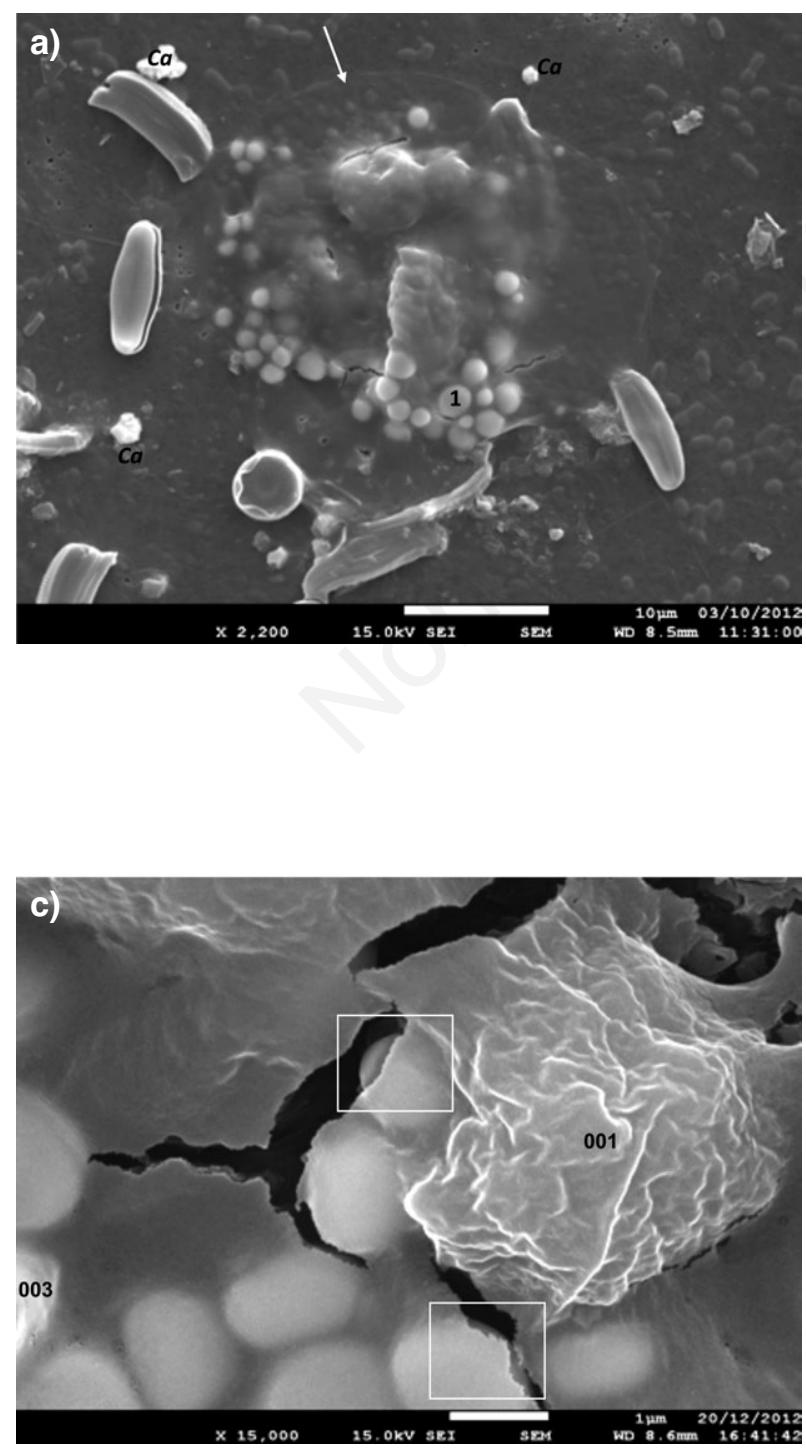

though we were not able to find a value for the solubility constant $K_{s}$ of crystalline benstonite (let alone for its amorphous, various species), we can approach the question by considering Stabel et al.'s (1991) data: these authors have computed, for lake Constance in summer, the $\left[\mathrm{Sr}^{2+}\right]=3.1610^{-5} \mathrm{M} \mathrm{L}^{-1}$ and $\left[\mathrm{Ba}^{2+}\right]=7.0810^{-5} \mathrm{M} \mathrm{L}^{-1}$ concentrations necessary to allow precipitation of strontianite $\left(\mathrm{SrCO}_{3} ; K s=10^{-9.03}\right)$ and witherite $\left(\mathrm{BaCO}_{3} ; K s=10^{-8.3}\right)$. Extending these figures to our case, it is obvious that $\mathrm{Sr}$ and $\mathrm{Ba}$ concentrations given in our Tab. 1 are much lower, meaning that these AEM carbonates cannot precipitate under the macroscopic $\mathrm{pH}$ and temperature conditions in lake Geneva. This is likely to apply also to benstonite-like minerals, the precipitation of which will necessitate micro-environments with extreme conditions (elevated $\mathrm{pH}$, increased ionic concentration and alkalinity).

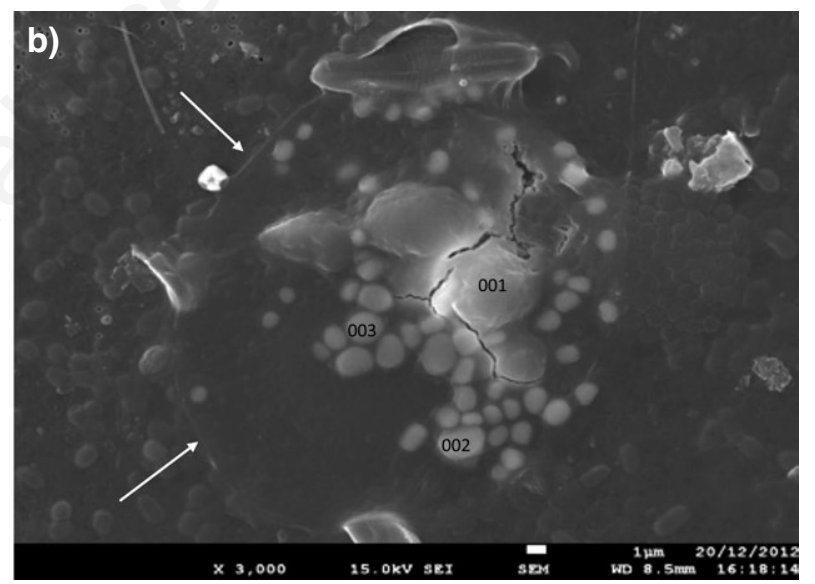

Fig. 6. a) View of microsphere cluster $S p 2 \_2$ (07.08.2012; from right part of Figure 4). Scale bar $=10 \mu \mathrm{m}$. Most parts of membrane are covered by mucilage $(0.2 \mu \mathrm{m}$ pores not visible), with a well-defined circular mass at centre (upper limit: white arrow). Numerous picoplankton spherical and subspherical cells $1 \mu \mathrm{m}$ or less in diameter. For analysis of microsphere $S p 2 \_2-001$ (1 at centre), see Tab. 2. A few $\mathrm{CaCO}_{3}(\mathrm{Ca})$ grains are visible. Diatoms are Achnanthes sp. Photograph taken prior to energy-dispersive $\mathrm{X}$ ray spectrometry (EDS) analysis of microspheres; $b$ ) view of microsphere cluster Sp2_3 (07.08.2012). Scale bar: 1 $\mu \mathrm{m}$. The microspheres are embedded in a subcircular mucilagineous mass, the left limit of which is quite sharp (arrows). Part 001 is heavily coated with mucilage, whereas 002 and 003 are much less so. Numerous picoplankton spherical and subspherical cells $1 \mu \mathrm{m}$ or less in diameter. Image taken prior to EDS analysis; c) close-up view of microspheres in cluster $S p 2$ 3 (07.08.2012) after EDS analysis. Scale bar: $1 \mu \mathrm{m}$. Mucilagenous part 001 has shrunk (compare with Fig. 6b), and the cracks in mucilagenous matrix have widened. In white frames: bare microspheres partially visible under torn mucilage. 


\section{Micro-environment}

This micro-environment is provided by the combination of picoplanktonic cells and a mucilage-like matrix in which microspheres have been observed to be embedded. Mucilage or EPS (exopolymeric substances) excreted by micro-organisms consists mainly of polysaccharides, which may contain functional groups for metal binding (Tien, 2002; Dittrich and Sibler, 2006, 2010). For instance, Alvarado Quiroz et al. (2006) have reported the strong binding capacity of sticky EPS-derived acid polysaccharide compounds for thorium (IV). Likewise, Acharya et al. (2009) showed that the ability of Synechococcus elongatus to bind uranium was due to its complexation with ligands within the EPS coating cell surface. Extracellular polymeric substances are known to stabilise microbial cells against highenergy environments and to provide a chemically protective microenvironment. They also serve to bind and concentrate $\mathrm{Ca}^{2+}$ and $\mathrm{Mg}^{2+}$ ions and raise the alkalinity of the surrounding water (Decho et al., 2005; Couradeau et al., 2012).

Mucilage has not yet been chemically characterised in the samples under study, but we interpret the low reflectance portions of the polycarbonate membranes (Fig. 3) as extra-cellular mucilage because of the following characteristics: obliteration of the $0.2 \mu \mathrm{m}$ pores (Figs. $5 \mathrm{a}$ and $6 \mathrm{a})$; coating of microspheres and presence of numerous picoplanktonic cells (Fig. 6b) in their midst; patch size reaching several tens of micrometers, thereby ruling out their attribution to flattened cells; and, of course, existence of AAEMC precipitates, which were never found outside the dark parts of the membranes.

The taxonomic attribution of the picoplankton associated with the mucilage will be clarified in a follow-up study. At the present stage, the densely packed, coccoid cells visible in July sample (Fig. 5a) could be tentatively attributed to two taxa: a member of i) the Chlorellaceae (Chlorella, Dictyosphaerium) or ii) the Chroococcaceae (Aphanocapsa, Aphanothece). Chlorella has been identified in the integrated phytoplankton counts, and these colonial taxa may have mucilaginous envelopes (Bock et al., 2011; Watanabe et al., 2006). Grouped under a small eukaryotes category, they have been found in summer in lakes Annecy, Bourget and Geneva (Personnic et al., 2009). The cyanophyta Aphanocapsa and Aphanothece have also been counted in the integrated phytoplankton sample. In August, most of the micro-organisms found close to the AAEMC microspheres (Fig. 6a) seem morphologically similar to a species of Synechococcus (Callieri and Stockner 2002), a cyanobacterium known for its association with EPS (Alvarado Quiroz et al., 2006). Besides, it is possible that Synechococcus and Chlorella coexist in the so-called association $Z$ reported by Callieri et al. (2006) in lake Maggiore. Epifluorescent microscopy, necessary to discriminate between pro- and eukaryotes (Callieri, 2010), could not be done at the time of sampling in summer 2012. However, water samples collected at the same GE3 station in June 2013 were examined by a combination of SEM and confocal laser scanning microscopy. Under blue excitation we found coccoid and rod-shaped cells appearing yellow [PE-cells of Callieri (2010)], and larger $(1-2 \mu \mathrm{m})$ cocci emitting in light red (pico-eukaryotes). This finding somewhat supports the taxonomic attribution presented for the summer samples.

On the basis of only SEM images, we cannot know whether the microspheres have precipitated next to, or at the expense of, picoplanktonic cells. The microspheres' aggregation in clusters and their almost perfectly spherical shape would stand in favour of the former alternative, whereas the presence of a pellicle surrounding an internal part might indicate precipitation at the cell surface, as observed by Schultze-Lam and Beveridge (1994) for a Synechococcus strain.

\section{The mineral phase}

Medium-magnification SEM images do not reveal any clear features on the microspheres' surface (Fig. 6c). They seem to be solid and compact inside, and the bubbly texture seen in Fig. 5b is an artifact clearly due to EDS analysis. This points towards an amorphous nature for the microspheres, characterising also the AAEMC intracellular granules of lake Alchichica (Couradeau et al., 2012). Interestingly, Addadi et al. (2003) stress the role of amorphous $\mathrm{CaCO}_{3}$ ( $\mathrm{ACC}$ or vaterite) in biomineralisation, as temporary storage deposits in various vesicles and transient precursor of calcite or aragonite (Konhauser and Riding, 2012; Mori et al., 2009; Gower, 2008). Finally, similar spherical shapes have been reported in amorphous barite precursors (Gonzalez-Muñoz et al., 2012).

Strictly speaking, types I to IV microspheres should take place in a tetraedric space with $\mathrm{Mg}, \mathrm{Ca}, \mathrm{Sr}$ and $\mathrm{Ba}$ apices to account for the composition given in Tab. 2. However, we have chosen to reduce this representation to a ternary $\mathrm{Ca}-\mathrm{Sr}-\mathrm{Ba}$ system: never exceeding a few atom percents, the $\mathrm{Mg}$ analytical results are somewhat doubtful and thus can be temporarily disregarded. The ternary plot of Fig. 7a shows the microspheres to be confined within the domain $\mathrm{Ca}>45 ; \mathrm{Sr}<10 ; \mathrm{Ba}<50$ (expressed here as \%). $\mathrm{The} \mathrm{Ba} / \mathrm{Ca}$ molar ratio varies between 0 and 1.1, indicating a very broad mixture of these cations compared to a relatively narrow $\mathrm{Sr}$ variability. In terms of a possible influence of the sampling date on the composition, the domains of occurrence of July and August microspheres on Fig. 7b being separated in places, while overlapping in others, the question cannot be solved for the moment. The plot of Fig. $7 \mathrm{c}$ has been used to establish a provisional typology of the microspheres (Tab. 4). The reality of five discrete types will have to be checked through the analysis of further microspheres, with consideration of the limited accuracy of EDS analyses. This will establish whether the chemical compo- 
sition forms a continuous series. What is clear from Fig. $7 \mathrm{c}$, though, is the impossibility of subdividing type I, as a great variability in the $\mathrm{Ba} / \mathrm{Ca}$ ratio exists between microspheres within a given cluster (represented in the figure as a line joining the squares). Type III differs from type II by the presence of $\mathrm{P}$ and $\mathrm{S}$ (Tab. 2). Type IV is, so far, represented by only one individual.

We have attributed type I microspheres to a benstonitelike amorphous phase. The benstonite mineral species is part of the Nickel-Struntz 05.AB Alkali-earth carbonates

Tab. 4. Indices of approximate stoichiometric formulae for microspheres.

\begin{tabular}{|c|c|c|c|c|}
\hline Microspheres & $\mathrm{Mg}$ & $\begin{array}{c}\mathrm{Mg}_{\mathrm{w}} \mathrm{Ca}_{\mathrm{x}}\left(\mathrm{Sr}_{\mathrm{y}} \mathrm{Ba}_{\mathrm{z}}\right)\left(\mathrm{CO}_{3}\right)_{13} \\
\mathrm{Ca}\end{array}$ & $\mathrm{Sr}$ & $\mathrm{Ba}$ \\
\hline Type I: average & 0.18 & 7.57 & 0.55 & 4.71 \\
\hline Type I: max Ba & 0.09 & 5.76 & 0.64 & 6.51 \\
\hline Type I: $\max \mathrm{Sr}$ & 0.24 & 6.28 & 1.27 & 5.21 \\
\hline Type I: min Ba & 0.35 & 10.83 & 0.31 & 1.52 \\
\hline Type II: average & 0.09 & 12.31 & 0.59 & 0.00 \\
\hline Lake Alchichica & 2.4 & 6.9 & 1.0 & 2.7 \\
\hline Benstonite (from Tab. 3) & 1.0 & 6.0 & 1.5 & 4.5 \\
\hline
\end{tabular}

Mg, magnesium; Ca, calcium; Sr, strontium; Ba, barium. Lake Alchichica benstonite-like phase stoichiometry is recomputed from Couradeau et al. (2012).

a)

\section{$\mathrm{Ba}$}

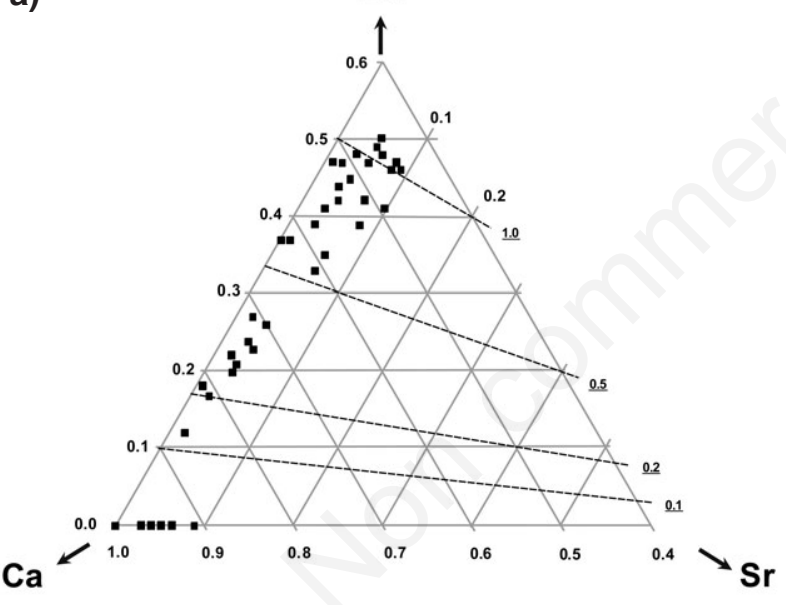

c)

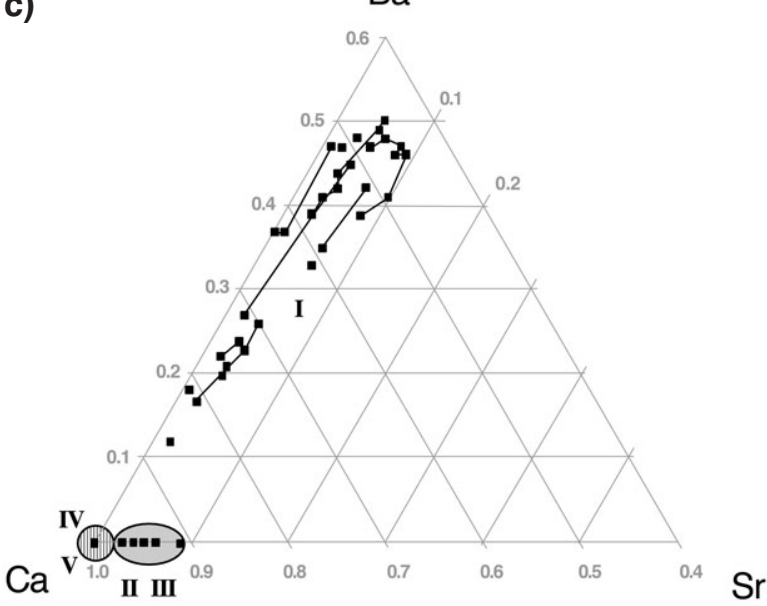

b)

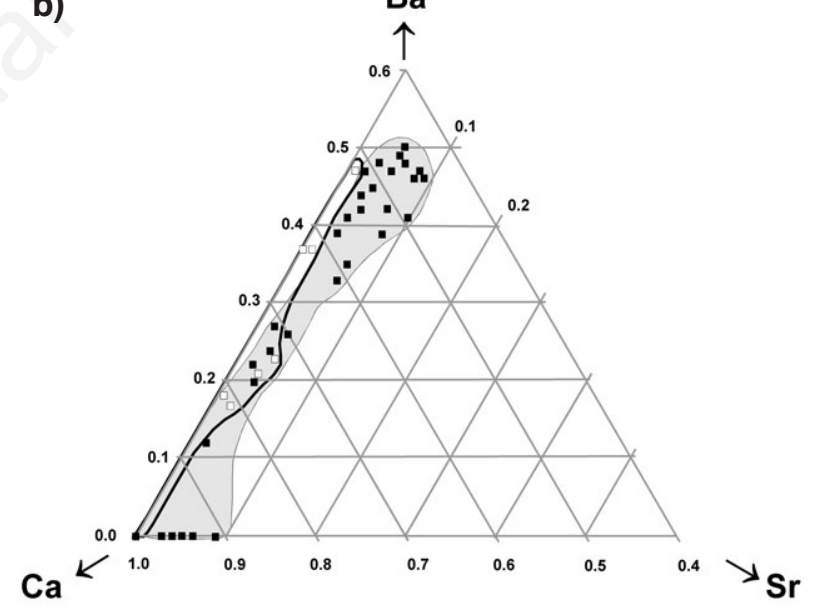

Fig. 7. Ternary diagram representation of $\mathrm{Ca}, \mathrm{Sr}$ and $\mathrm{Ba}$ molar proportions in lake Geneva microspheres. a) The 55 analysed microspheres are all located in the domain limited by $\mathrm{Ca}>0.45$, $\mathrm{Sr} \leq 0.1$ and $\mathrm{Ba}<0.5$. Dotted lines labelled with underlined numbers represent the $\mathrm{Ba} / \mathrm{Ca}$ molar ratio; b) microspheres distribution according to the date. Open squares, July; black squares, August; c) microspheres typology I: $\{\mathrm{Ca} \mathrm{Sr} \mathrm{Ba}\}$; II: $\{\mathrm{Ca} \mathrm{Sr}\}$; III: $\{\mathrm{Ca} \mathrm{P} \mathrm{Sr}\}$; IV: $\{\mathrm{Ca}\} ; \mathrm{V}:\{\mathrm{Ca} \mathrm{P}\}$. The individual microspheres within a cluster are linked by a black line. Isolated squares indicate that only one analysis was performed. Stippled circle: domain of groups IV and V. Grey ellipse: domain of groups II and III. 
category (Barthelemy, 2012; Jolyon, 2012). Its basic formula may be written as $(\mathrm{Ba}, \mathrm{Sr})_{6}(\mathrm{Ca}, \mathrm{Mn})_{6} \mathrm{Mg}\left(\mathrm{CO}_{3}\right)_{13}$, with $\mathrm{Ba}, \mathrm{Sr}$ and manganese $(\mathrm{Mn})$ varying in proportions. In the Magnet-Cove variety (Anthony et al., 2012), the formula is $\left(\mathrm{Ba}_{5.27} \mathrm{Sr}_{0.73}\right) \mathrm{Ca}_{6.00}\left(\mathrm{Mg}_{0.79} \mathrm{Ca}_{0.12} \mathrm{Mn}_{0.09}\right)\left(\mathrm{CO}_{3}\right)_{13}$ or simply $\mathrm{Ba}_{6} \mathrm{Ca}_{6} \mathrm{Mg}\left(\mathrm{CO}_{3}\right)_{13}$. The variability in composition of different species of benstonite is illustrated in Tab. 3 (from literature) and Tab. 4 (our samples).

In the absence of any significant amount of $\mathrm{Mg}$ and $\mathrm{Ba}$, types II, III and IV chemical compositions could be those of an amorphous $\mathrm{CaCO}_{3}$ analogous to vaterite with varying amounts of $\mathrm{Sr}$. The molar $\mathrm{Sr} / \mathrm{Ca}$ ratio in these types of microspheres is around 0.05 (Tab. 5), equal to that found by Lauchnor et al. (2013) in microbially induced $\mathrm{Ca}$ and $\mathrm{Sr}$ co-precipitates. This value lies in the miscibility region of the phase diagram of $\mathrm{Sr}_{x} \mathrm{Ca}_{1-\mathrm{x}} \mathrm{CO}_{3}$ solids (Ruiz-Hernandez et al., 2010). As already mentioned, in lake Constance this ratio - computed for well crystallised calcite - is only 0.0084 (Stabel et al., 1991). For ostracod valves in lake Geneva, $\mathrm{Sr} / \mathrm{Ca}$ never exceeds 0.0025 (Decrouy et al., 2012). These comparisons seem to indicate a higher $\mathrm{Sr}$ sequestration potential for the processes producing microspheres.

The EDS analyses being of semi-quantitative nature, caution has to be exercised when comparing our micros-
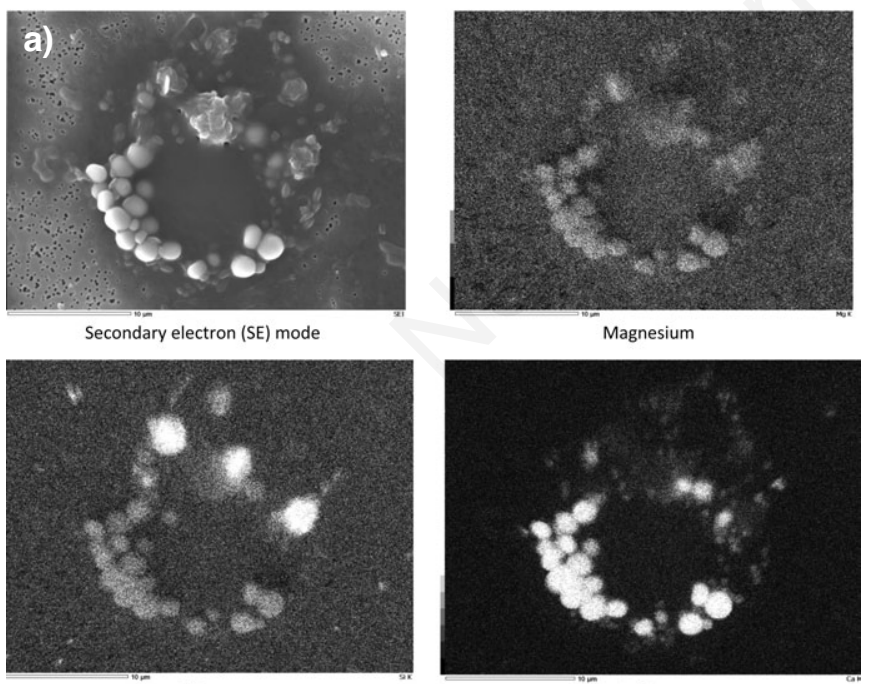

Silicon

Calcium

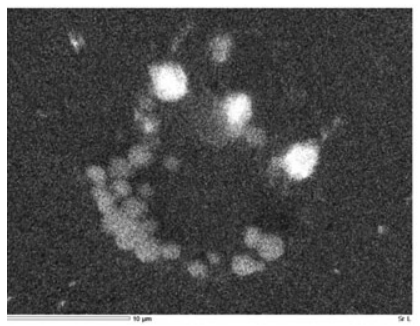

Strontium

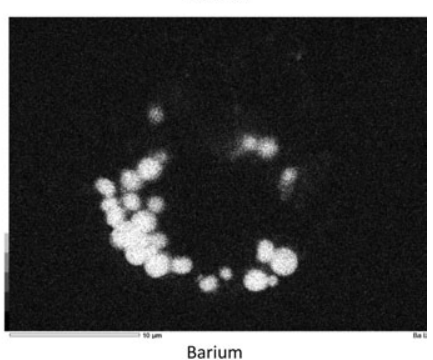

pheres' composition to that of mineralogical or lake Alchichica benstonite-like phase, the latter given as $\left(\mathrm{Sr}_{1.0} \mathrm{Ba}_{2.7} \mathrm{Mg}_{1.4} \mathrm{Ca}_{0.9}\right) \mathrm{Ca}_{6.0} \mathrm{Mg}\left(\mathrm{CO}_{3}\right)_{13}$ (Tab. 5, last column). Compared to synthetic benstonite (Tab. 4), lake Geneva microspheres may be higher in $\mathrm{Ca}$ (type I, max. $\mathrm{Sr}$ and min. $\mathrm{Ba}$ ), and are always lower in $\mathrm{Mg}$ and $\mathrm{Sr}$. All the formulas for mineralogical benstonite found in literature have in common an index very close to 6.0 for $\mathrm{Ca}$. This is the case for some lake Geneva type I microspheres, but not for Alchichica granules (6.9). As regard to this and the rather imprecise definition of benstonite, we will consider the attribution of type I microspheres to this mineral phase as tentative only.

Some interesting trends emerge from the element ratios given in Tab. 5. First, the AEM molar ratios are not the same in water and in the microspheres; with respect to $\mathrm{Ca}$, $\mathrm{Mg}$ is depressed in the precipitates whereas $\mathrm{Sr}$ (average 0.06 in precipitates $v s 0.0054$ in water) and especially $\mathrm{Ba}$ (0.30-0.60 vs 0.00012) are strongly enriched in the microspheres. The dominance of $\mathrm{Sr}$ in water $(\mathrm{Sr} / \mathrm{Ba}=44.3)$ is inverted in type I microspheres $(\mathrm{Sr} / \mathrm{Ba}=0.12)$. This $\mathrm{Ba}$ enrichment is similar to that existing (as barite) in desmids (Wilcock et al., 1989) and marine bacteria (GonzalezMuñoz et al., 2012). This could reflect the affinity of Ba for biota (Martin and Knauer, 1973; McGrath et al., 1989).

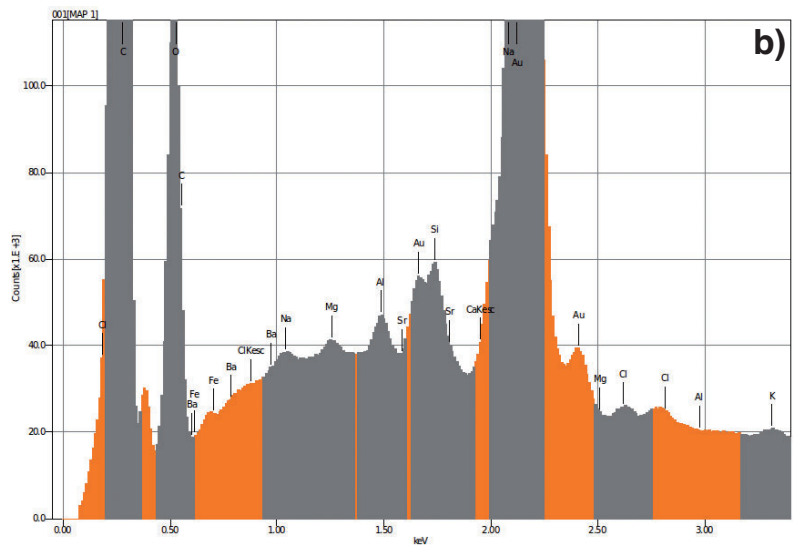

Fig. 8. a) Energy-dispersive $X$ ray spectrometry (EDS) mapping of cluster Sp2_4 (07.08.2012), embedded in mucilage. Scale bar: $10 \mu \mathrm{m}$. Apart from the microspheres, presence of siliceous particles and picoplanktonic cells $(1 \mu \mathrm{m}$ diameter, visible in secondary electron mode). Group IIA metals mineralisation is restricted to bright, $>2 \mu \mathrm{m}$ microspheres. Strontium map is confounded with silicon (spectral peak overlap). Notice the weaker magnesium signature, matching well the Sp2_4-001 point analysis (not shown); b) Extract of spectrum corresponding to the mapping of cluster Sp2_4. X-axis: energy in keV; Y-axis: counts $\times 10^{3}$. Main peaks are shown in dark grey. Si $K(1.73$ $\mathrm{keV})$ and $\mathrm{Sr} L(1.8 \mathrm{keV})$ peaks are very close. 
Tab. 5. Selected element atom and molar ratios of water at $5 \mathrm{~m}$ depth, in microspheres and various species of benstonite-like phases.

\begin{tabular}{|c|c|c|c|c|c|c|c|c|}
\hline Cation & $\begin{array}{c}\text { Water } \\
10.07 .2012 \\
5 \mathrm{~m}\end{array}$ & $\begin{array}{c}\text { Water } \\
07.08 .2012 \\
5 \mathrm{~m}\end{array}$ & $\begin{array}{c}\text { Microspheres } \\
\text { type I } \\
\text { (average) }\end{array}$ & $\begin{array}{c}\text { Microspheres } \\
\text { type II } \\
\text { (average) }\end{array}$ & $\begin{array}{c}\text { Microspheres } \\
\text { type III }\end{array}$ & $\begin{array}{c}\left(\mathrm{Sr}_{0.5} \mathrm{Ba}_{5.5}\right)^{*} \\
\text { theoretical } \\
1\end{array}$ & $\begin{array}{c}\left(\mathrm{Ba}_{4.5} \mathrm{Sr}_{1.5}\right)^{*} \\
\text { synthetic } \\
\text { EDS }\end{array}$ & $\begin{array}{c}\left(\mathrm{Ba}_{2.7} \mathrm{Sr}_{1.0} \mathrm{Mg}_{1.4} \mathrm{Ca}_{0.9}\right) \\
\text { Couradeau et al. } \\
(2012)\end{array}$ \\
\hline \multirow[t]{2}{*}{$\overline{\mathrm{Mg} / \mathrm{Ca}}{ }^{\circ}$} & 0.14 & 0.15 & 0.01 & 0.01 & 0.01 & 0.10 & 0.06 & 0.34 \\
\hline & 0.23 & 0.25 & 0.02 & 0.01 & 0.02 & 0.17 & 0.11 & 0.56 \\
\hline \multirow[t]{2}{*}{$\mathrm{Sr} / \mathrm{Ca}$} & 0.012 & 0.012 & 0.15 & 0.11 & 0.12 & 0.55 & 0.54 & 0.15 \\
\hline & 0.0053 & 0.0055 & 0.07 & 0.05 & 0.06 & 0.25 & 0.24 & 0.07 \\
\hline \multirow[t]{2}{*}{$\mathrm{Ba} / \mathrm{Ca}$} & 0.00041 & 0.00041 & 1.96 & 1.01 & & 2.57 & 3.20 & 0.39 \\
\hline & 0.00012 & 0.00012 & 0.62 & 0.29 & & 0.75 & 0.93 & 0.11 \\
\hline \multirow[t]{2}{*}{$\mathrm{Sr} / \mathrm{Mg}$} & 0.081 & 0.078 & 9.81 & 22.7 & 8.56 & 5.41 & 8.41 & 0.45 \\
\hline & 0.022 & 0.022 & 3.10 & 6.29 & 2.40 & 1.50 & 2.33 & 0.12 \\
\hline \multirow[t]{2}{*}{$\mathrm{Sr} / \mathrm{Ba}$} & 28.3 & 29.4 & 0.07 & & & 0.21 & 0.17 & 0.39 \\
\hline & 44.3 & 46.1 & 0.12 & & & 0.33 & 0.26 & 0.61 \\
\hline
\end{tabular}

EDS, energy dispersive X-ray spectrometry; $\mathrm{Mg}$, magnesium; $\mathrm{Ca}$, calcium; $\mathrm{Sr}$, strontium; Ba, barium. ${ }^{*}$ First row: variable cations, in addition to fixed $\mathrm{Mg}_{1} \mathrm{Ca}_{6}$; ${ }^{\circ}$ top: atom ratio; bottom: molar ratio.

An explanation for the differential enrichment of $\mathrm{Sr}$ and $\mathrm{Ba}$ in the microspheres could be traced in Rogerson et al. (2008), who found that ions other than Ca can be chelated into biofilm EPS, and that this process was highly selective in favour of those ions with small charge density.

Second, with respect to lake Alchichica AAEMC granules, microspheres in lake Geneva are much lower in $\mathrm{Mg}$ $(\mathrm{Mg} / \mathrm{Ca}=0.02$ vs 0.56) and much higher in $\mathrm{Ba}$ $(\mathrm{Ba} / \mathrm{Ca}=0.30-0.60$ vs 0.11$)$. This reflects the highly alkaline character of lake Alchichica waters (Tab. 1, bottom row), with high $\mathrm{Mg}$ and low $\mathrm{Ca}, \mathrm{Sr}$ and $\mathrm{Ba}$ concentrations.

\section{CONCLUSIONS}

Type I amorphous microspheres (0.6-3 $\mu \mathrm{m}$ diameter) containing $\mathrm{Mg}, \mathrm{Ca}, \mathrm{Sr}$ and $\mathrm{Ba}$ found in the epilimnion of lake Geneva in summer 2012 have been tentatively interpreted as a benstonite-like mineral phase. Types II, III and $\mathrm{IV}$, without $\mathrm{Ba}$ and with variable $\mathrm{Sr}$, could be ascribed to a vaterite-like phase, a precursor of calcite. All these types are characteristically precipitated within a mucilaginous matrix embedding picoplanktonic cells.

Type I AAEMC microspheres' chemical composition, determined semi-quantitatively by EDS, bears some analogy to that of cyanobacterial intracellular inclusions found in alkaline lake Alchichica (Mexico) microbialites. In lake Geneva, however, the microspheres are pelagic, seemingly extracellular, and contain less $\mathrm{Mg}$ but more $\mathrm{Ba}$.

Discovered a posteriori in dried suspended matter deposited on filters, these precipitates could be studied only in a preliminary manner. In the context of the little-known $\mathrm{Sr}$ and $\mathrm{Ba}$ cycles in freshwater, their occurrence raises a series of questions, which will be dealt with in a dedicated study planned for 2013. Is the typology found in 2012 a permanent feature, and how can it be explained? What is the taxonomic attribution of the picoplanktonic cells spatially associated with microspheres within the mucilage? Precipitating in epilimnion, do the microspheres survive in hypolimnion, and possibly in the sediment? Finally, the internal structure and exact composition of the AAEMC precipitates (as carbonate or phosphate in type V?) and associated mucilage should be investigated with adequate tools in order to gain a proper understanding of this peculiar process of AEM sequestration.

\section{ACKNOWLEDGMENTS}

We are indebted to Sophie Lavigne, who carried out phytoplankton counting and determination. We thank François Gischig, Cédric Schnyder (Muséum d'Histoire Naturelle, Geneva, Switzerland) and Marie-Caroline Pinget (Department of Mineralogy, Université de Genève, Geneva, Switzerland) for preparation, Raman spectroscopy and X-ray diffraction of benstonite samples, respectively. Mathieu Coster was of great help in the synthesis of benstonite. Vincent Ebener and Nathalie Dupont have aptly and faithfully collected samples in the field, and water analyses were carried out by the Service de l'écologie de l'eau (SECOE) analytical laboratory. The availability of SEM facilities at the Department of Geology (Université de Genève) is gratefully acknowledged. We are thankful to the reviewers and Journal's editors for their help in improving an earlier version of the manuscript.

\section{REFERENCES}

Acharya C, Joseph D, Apte SK, 2009. Uranium sequestration by a marine cyanobacterium, Synechococcus elongatus strain BDU/75042. Bioresource Technol. 100:2176-2181. Addadi L, Raz S, Weiner S, 2003. Taking advantage of disorder: 
amorphous calcium carbonate and its role in biomineralization. Adv. Mater. 15:959-970.

Alvarado Quiroz NG, Hung C-C, Santschi P, 2006. Binding of thorium (IV) to carboxylate, phosphate and sulfate functional groups from marine exopolymeric substances (EPS). Mar. Chem. 100:337-353.

Anneville O, Pelletier J-P, 2000. Recovery of Lake Geneva from eutrophication. Arch. Hydrobiol. 148:607-624.

Anneville O, Souissi S, Ibanez F, Ginot V, Druart JC, Angeli N, 2002. Temporal mapping of phytoplankton assemblages in Lake Geneva: annual and interannual changes in their patterns of succession. Limnol. Oceanogr. 47:1355-1366.

Anthony JW, Bideaux RA, Bladh KW, Nichols MC, 2012. Handbook of mineralogy. Mineralogical Society of America ed., Chantilly: 628 pp.

Ball JW, Nordstrom DK, 1991. User's manual for WATEQ4F, with revised thermodynamic data base and test cases for calculating speciation of major, trace, and redox elements in natural waters. Available from: http://wwwbrr.cr.usgs.gov/ projects/GWC_chemtherm/pubs/wq4fdoc.pdf

Barthelemy D, 2012. Mineralogy database. Available from: http://webmineral.com/

Belykh OI, Sorokovikova EG, 2003. Autotrophic picoplankton in Lake Baikal: Abundance, dynamics, and distribution. Aquat. Ecosyst. Health 6:251-261.

Bock C, Krienitz L, Pröschold T, 2011. Taxonomic reassessment of the genus Chlorella (Trebouxiophyceae) using molecular signatures (barcodes), including description of seven new species. Fottea 11:293-312.

Brook AJ, 1980. Barium accumulation by desmids of the genus Closterium (Zygnemaphyceae). Brit. Phycol. J. 15:261-264.

Callieri C, 2010. Single cells and microcolonies of freshwater picocyanobacteria: a common ecology. J. Limnol. 69:257277.

Callieri C, Caravati E, Morabito G, Oggioni A, 2006. The unicellular freshwater cyanobacterium Synechococcus and mixotrophic flagellates: evidence for a functional association in an oligotrophic, subalpine lake. Freshwater Biol. 51:263-273.

Callieri C, Piscia R, 2002. Photosynthetic efficiency and seasonality of autotrophic picoplankton in Lago Maggiore after its recovery. Freswater Biol. 47:941-956.

Callieri C, Stockner JC, 2002. Freshwater autotrophic picoplankton: a review. J. Limnol. 61:1-14.

CIPEL, 2011. General conclusions on the state of Lake Geneva in 2010. Commission Internationale pour la Protection du Léman ed., Nyon.

Couradeau E, Benzerara K, Gérard E, Moreira D, Bernard S, Brown Jr GE, López-García P, 2012. An early-branching microbialite cyanobacterium forms intracellular carbonates. Science 336:459-462

Decho AW, Visscher PT, Reid RP, 2005. Production and cycling of natural microbial exopolymers (EPS) within a marine stromatolite. Palaeogeogr. Palaeocl. 219:71-86.

Decrouy L, Vennemann TV, Ariztegui D, 2012. Mg/Ca and $\mathrm{Sr} / \mathrm{Ca}$ of ostracod valves from living species of Lake Geneva. Chem. Geol. 314-317:45-56.

Dittrich M, Kurz P, Wehrli B, 2004. The role of autotrophic picocyanobacteria in calcite precipitation in an oligotrophic lake. Geomicrobiol. J. 21:45-53.
Dittrich M, Obst M, 2004. Are picoplankton responsible for calcite precipitation in lakes? Ambio 33:559-564.

Dittrich M, Sibler S, 2006. Influence of $\mathrm{H}^{+}$and calcium ions on surface functional groups of Synechococcus PCC 7942 cells. Langmuir 22:5435-5442.

Dittrich M, Sibler S, 2010. Calcium carbonate precipitation by cyanobacterial polysaccharides, p. 51-63. In: H.M. Pedley and M. Rogerson (eds.), Tufas and speleothems: unravelling the microbial and physical controls. Geological Society of London Publ.

Dupraz C, Reid RP, Braissant O, Decho AW, Norman RS, Vissche PT, 2009. Processes of carbonate precipitation in modern microbial mats. Earth-Sci. Rev. 96:141-162.

Fahnenstiel GL, Carrick HJ, Rogers CE, Sicko-Goad L, 1991. Red fluorescing phototrophic picoplankton in the Laurentian Great Lakes: what are they and what are they doing? Int. Rev. Hydrobiol. 76:603-616.

Finlay BJ, Hetherington NB, Davison W, 1983. Active biological participation in lacustrine barium chemistry. Geochim. Cosmochim. Ac. 47:1325-1329.

Gallina N, Anneville O, Beniston M, 2011. Impacts of extreme air temperatures on cyanobacteria in five deep peri-alpine lakes. J. Limnol. 70:186-196.

Glass-Haller L, 2010. Microbial and geochemical characterization of a contaminated freshwater ecosystem (the case of Vidy Bay, Lake Geneva, Switzerland). University of Geneva ed., Geneva: 186 pp.

Gonzalez-Muñoz MT, Martinez-Ruiz F, Morcillo F, MartinRamos JD, Paytan A, 2012. Precipitation of baryte by marine bacteria: a possible mechanism for marine barite formation. Geology 40:675-678.

Gower L, 2008. Biomimetic model systems for investigating the amorphous precursor pathway and its role in biomineralization. Chem. Rev. 108:4551-4627.

Groleau A, Sarazin G, Vinçon-Leite B, Tassin B, Quiblier-Llobéras C, 2000. Tracing calcite precipitation with specific conductance in a hard water alpine lake (Lake Bourget). Water Res. 43:4151-4160.

Hernández Mariné M, Clavero E, Roldán M, 2004. Microscopy methods applied to research on cyanobacteria. Limnetica 23:179-185.

Hood WC, Steidl PF, 1973. Synthesis of benstonite at room temperature. Am. Mineral. 58:341-343.

Hood WC, Steidl PF, Tschopp DG, 1974. Precipitation of norsethite at room temperature. Am. Mineral. 59:471-474.

Jansson C, Northen T, 2010. Calcyfying cyanobacteria. The potential of biomineralization for carbon capture and storage. Curr. Opin. Biotech. 21:1-7.

Jaquet J-M, Favarger P-Y, Peter A, Vernet J-P, 1983. [Premières données sur la matière en suspension dans le Léman]. [Book in French]. Institut Forel, University of Geneva ed., Geneva: 83 pp. Available from: http://archive-ouverte.unige.ch/vital/ access/manager/Repository/unige: 27100

Jaquet J-M, Nembrini G, Garcia J, Vernet J-P, 1982. The manganese cycle in Lac Léman (Switzerland): the role of Metallogenium. Hydrobiologia 91-92:323-340.

Jeandel C, Tachikawa K, Bory A, Dehairs F, 2000. Biogenic barium in suspended and trapped material as a tracer of export production in the tropical NE Atlantic (EUMELI sites). Mar. Chem. 71:125-142. 
Jolyon R, 2012. Mindat.org, the mineral and locality database. Available from: http://www.mindat.org

Kelts K, Hsu KJ, 1978. Freshwater carbonate precipitation, p. 295-323. In A. Lerman (ed.), Lakes: chemistry, geology, physics. Springer-Verlag.

Konhauser K, Riding R, 2012. Bacterial biomineralization, p. 105-130. In: A.H. Knoll, D.E. Canfield and K.O. Konhauser (eds.), Fundamentals of geobiology. Blackwell Publ.

Krejci MR, Wassermann B, Finney L, McNulty I, Legnini D, Vogt S, Joester D, 2011. Selectivity of biomineralization of barium and strontium. J. Struct. Biol. 176:192-202.

Lauchnor EG, Schulz LN, Bugni S, Mitchell AC, Cunningham $\mathrm{AB}$, Gerlach R, 2013. Bacterially induced calcium carbonate precipitation and strontium coprecipitation in a porous media flow system. Environ. Sci. Technol. 47:1557-1564.

Lazarotto J, Klein A, 2012. Physical-chemical changes in the waters of Lake Geneva. Available from: http://www.cipel. org/wp-content/uploads/2012/11/Evolution-physico-chimique.pdf

Lee BD, Apel WA, Walton MR, 2006. Calcium carbonate formation by Synechococcus sp. strain PCC 8806 and Synechococcus sp. strain PCC 8807. Bioresource Technol. 97:2427-2434.

Lynn DH, 2010. The ciliated protozoa: characterization, classification, and guide to the literature. Springer, Amsterdam: $605 \mathrm{pp}$.

Martin JH, Knauer GA, 1973. The elemental composition of plankton. Geochim. Cosmochim. Ac. 37:1639-1653.

McGrath M, Davison W, Hamilton-Taylor J, 1989. Biogeochemistry of barium and strontium in a softwater lake. Sci. Total Environ. 87/88:287-295.

Mori Y, Enomae T, Isogai A, 2009. Preparation of pure vaterite by simple mechanical mixing of two aqueous salt solutions. Mater. Sci. Eng. C29:1409-1414.

Parkhurst DL, Appelo CAJ, 1999. User's guide to PHREEQC (version 2): a computer program for speciation, batch reaction, one-dimensional transport, and inverse geochemical calculations. US Department of the Interior ed., denver: 309 pp. Available from: ftp://brrftp.cr.usgs.gov/pub/dlpark/ geochem/unix/phreeqc/manual.pdf

Pereira S, Zille A, Micheletti E, Moradas-Ferreira P, De Philippis R, Tamagnini P, 2009. Complexity of cyanobacterial exopolysaccharides : composition, structures, inducing factors and putative genes involved in their biosynthesis and assembly. FEMS Microbiol. Rev. 33:917-941.

Personnic S, Domaizon I, Dorrigo U, Berdjeb L, Jacquet S, 2009. Seasonal and spatial variability of virio-, bacterio-, and picoplanktonic abundance in three perialpine lakes. Hydrobiologia 627:99-116.

Plée K, Ariztegui D, Martini R, Davaud E, 2008. Unravelling the microbial role in ooid formation - results of an in situ experiment in modern freshwater Lake Geneva in Switzerland. Geobiology 6:341-350.

Rogerson M, Pedley HM, Wadhawan JD, Middleton R, 2008. New insights into biological influence on the geochemistry of freshwater carbonate deposits. Geochim. Cosmochim. Ac. 72:4976-4987.

Ruiz-Hernandez SE, Grau-Crespo R, Ruiz-Salcador AR, De Leuw NH, 2010. Thermochemistry of strontium incorporation in aragonite from atomistic simulations. Geochim. Cosmochim. Ac. 74:1320-1328.

Sanchez-Moral S, Luque L, Cañaveras JC, Laiz L, Jurado V, Hermosin B, Saiz-Jimenez C, 2004. Bioinduced barium precipitation in St. Callixtus and Domitilla catacombs. Ann. Microbiol. 54:1-12.

Schultze-Lam S, Beveridge TJ, 1994. Nucleation of celestite and strontianite on a cyanobacterial S-Layer. Appl. Environ. Microb. 60:447-453.

Sondi I, Matijevic E, 2003. Homogenous precipitation by enzyme-catalyzed reactions. 2. Strontium and Barium carbonates. Chem. Mater. 15:1322-1326.

Stabel H-H, 1986. Calcite precipitation in Lake Constance. Limnol. Oceanogr. 31:1081-1093.

Stabel H-H, 1989. Coupling of strontium and calcium cycles in Lake Constance. Hydrobiologia 176-177:323-329.

Stabel H-H, Kleiner J, Merkel P, Sinemus HW, 1991. [Stoffkreislaüfe ausgewählter Spurenelemente im Bodensee]. [Article in German]. Vom Wasser 76:73-91.

Stabel H-H, Küchler-Krischun J, Kleiner J, Merkel P, 1986. Removal of strontium by coprecipitation in Lake Constance. Naturwissenschaften 73:551-553.

Sugiayma M, Hori T, Kihara S, Matsui M, 1992. A geochemical study on the specific distribution of barium in Lake Biwa, Japan. Geochim. Cosmochim. Ac. 56:597-605.

Sun D-M, Wu Q-S, Ding Y-P, 2006. A novel method for crystal control: synthesis and design of strontium carbonate with different morphologies by supported liquid membrane. Sol. St. Phen. 39:544-549.

Tadonleke RD, 2012. Primary production and chlorophyll a biomass in Lake Geneva. Campagne 2011:78-84.

Tien C-J, 2002. Biosorption of metal ions by freshwater algae with different surface characteristics. Process Biochem. 38:605-613.

Watanabe K, Imase M, Sasaki K, Ohmura N, Saiki H, Tanaka $\mathrm{H}, 2006$. Composition of the sheath produced by the green alga Chlorella sorokiniana. Lett. Appl. Microbiol. 42:538543.

Wilcock JR, Perry CC, Williams RJP, Brook AJ, 1989. Biological minerals formed from strontium and barium sulphates. II. Crystallography and control of mineral morphology in desmids. P. Roy. Soc. Lond. B Bio. 238:203-221.

Winder M, 2009. Photosynthetic picoplankton dynamics in Lake Tahoe: temporal and spatial niche partitioning among prokariotic and eukaryotic cells. J. Plankton Res. 31:13071320 .

Wu Q-S, Sun D-M, Liu H-J, Ding Y-P, 2004. Abnormal polymorph conversion of calcium carbonate and nano-self assembly of vaterite by a supported liquid membrane system. Cryst. Growth Des. 4:717-720. 